\author{
Vanda Brandić \\ E-mail: vanda.brandic@riteh.hr \\ Damir Kolić \\ E-mail: dkolic@riteh.hr \\ University of Rijeka, Faculty of Engineering, Vukovarska 58, Rijeka, Croatia
}

\title{
PWBS Best Practice Analysis of Two Shipyards
}

\begin{abstract}
The product work breakdown structure (PWBS) of a shipyard defines both the interim product breakdown and the work breakdown. Shipyards that have a well defined PWBS can effectively reduce man-hours by applying techniques of group technology and hull block construction method (HBCM). In this paper, a case study of typical double-bottom blocks of both a car carrier and a self-unloading bulker vessel designed in different shipyards, are analyzed. Since each shipyard applies a different interim product breakdown structure (PBS), a best practice tabular comparision demonstrates which PBS is better. The conclusion is that different shipyards under the same corporation should objectively apply best practice methods which recognize and apply what is best from one yard to the other yard and vice-versa. This will raise the competitiveness level of both shipyards.
\end{abstract}

Keywords: Product breakdown structure-PWBS, shipbuilding, hull-block construction method- HBCM

\section{Introduction}

The product work breakdown structure (PWBS) derives from the Society of Naval Architects and Marine Engineers (SNAME) research in shipbuilding and related papers [1]. The development of interim products which are assembled at specific workstations and defined with the necessary tools and equipment and necessary man-power according to trade. The purpose of this paper is to analyze the PWBS breakdown of ships from two different shipyards. As a result of the analysis, the shipyard with the superior PWBS should be chosen as a model for the other shipyard, since the two shipyards are part of the same corporation or group. Therefore, it is logical and practical that based upon the conclusions made in this paper, that the management recognize the benefits of both yards in order to adopt a best practice.

The comparison and PWBS analysis of two different shipyards which are under the same management is ideal for best practice analysis and implementation. The 
more efficient production methods of each shipyard could and should be stressed and implemented by both shipyards. This will improve the competitiveness of both shipyards, and yield man-hour savings and profit for the corporation.

The case study of this paper analyzed the breakdown of the double bottom section of a 24.900 tons self-unloading bulk carrier vessel and the breakdown of the double bottom of a 7000 vehicle car carrier. This includes the interim products of both vessels.

\section{Background}

Design for production can defined as the need to design a vessel which is in compliance with Owner desires and Classification society and International maritime rules, while also being optimized with shipyard production facilities [2]. DFP is in correlation with both group technology and PWBS because it is necessary to develop the detailed production drawings and the interim products according to group technology principles. This way big panels are assembled in one assembly line, whereas smaller panels known as micro-panels are assembled in another assembly line [3-6].

Data mining methods to make predictions in the shipbuilding process is practical for shipyard management to decide to optimize the panel assembly line [7]. This yields significant savings in the core assembly process of any shipyard.

Value stream mapping methodology has been demonstrated to aid in improving panel assembly process $[8,9]$, the built-up panel assembly process $[10,11]$ and the large block erection process [12]. However, the purpose of this paper is to determine and demonstrate how the PWBS of two shipyards should be compared, and the one with the best system should be adopted by the other.

\section{Case study}

The bulk carrier vessel was designed and built in the 3. Maj shipyard using a product work breakdown structure. The second ship, a car carrier was designed by the Uljanik shipyard which is also the base of the Uljanik group. Depending on the work load of each shipyard, the designs from one yard are sometimes used to build the ship in the second shipyard, in this case study at the 3. Maj shipyard.

There are three main design phases. These include contract design, classification society design and finally production/detail design. While the contract design does have an influence on how the ship may be broken down especially from drawings such as the midship section, the production/detail design phase is the area where PWBS is implemented. Therefore, whereas the contract design and classification design of both shipyards could remain identical, it is certainly a necessity to adapt and transform the detailed design to be in compliance with the different shipyard facilities, since no two shipyards have the same exact facilities. Therefore, the detailed design will also have to be transformed to comply with the different facilities and constraints. 


\subsection{Self-unloading bulk carrier}

The self-unloading bulk carrier has a deadweight of 24.900 tons, a length of 198 meters and a beam of 23.77 meters. It is designed to navigate through the St. Lawrence Seaway which connects the Canadian/US Great Lakes to the Atlantic Ocean.

The double bottom section of the parallel middle-body section was analyzed (See Figure 1). It is designated as VT which stands for very large three dimensional section and it has a mass of 148 tons and is made up of the following interim products: panels, built-up panels, sections, three-dimensional sections and three different types of micro-panels. A large panel (P) is made up of butt-welded steel plates stiffened with longitudinal profiles. A built-up panel (KP) is made up of a big panel (P) fitted with multiple micropanels. Micropanels are designated as robotically assembled (CR), semi-automatically assembled (CA) and manually assembled (MP) micropanels. The product breakdown structure is as follows (See Figure 2).

- P111 and P211 (Large panels)

- KP11 and KP21 (Built-up panels)

- T01, T11, T21 (Three dimensional sections)

- S14, S15, S24, S25 (Sections)

- MP003, MP032, MP033

- CR003, CR004

- CA070-CA079

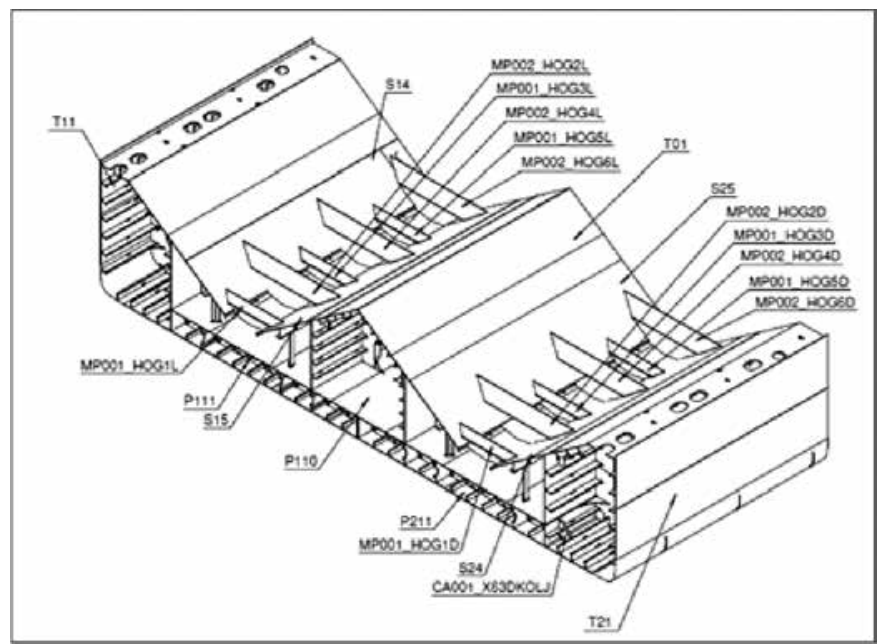

Figure 1. Double bottom erection block of the bulker vessel 


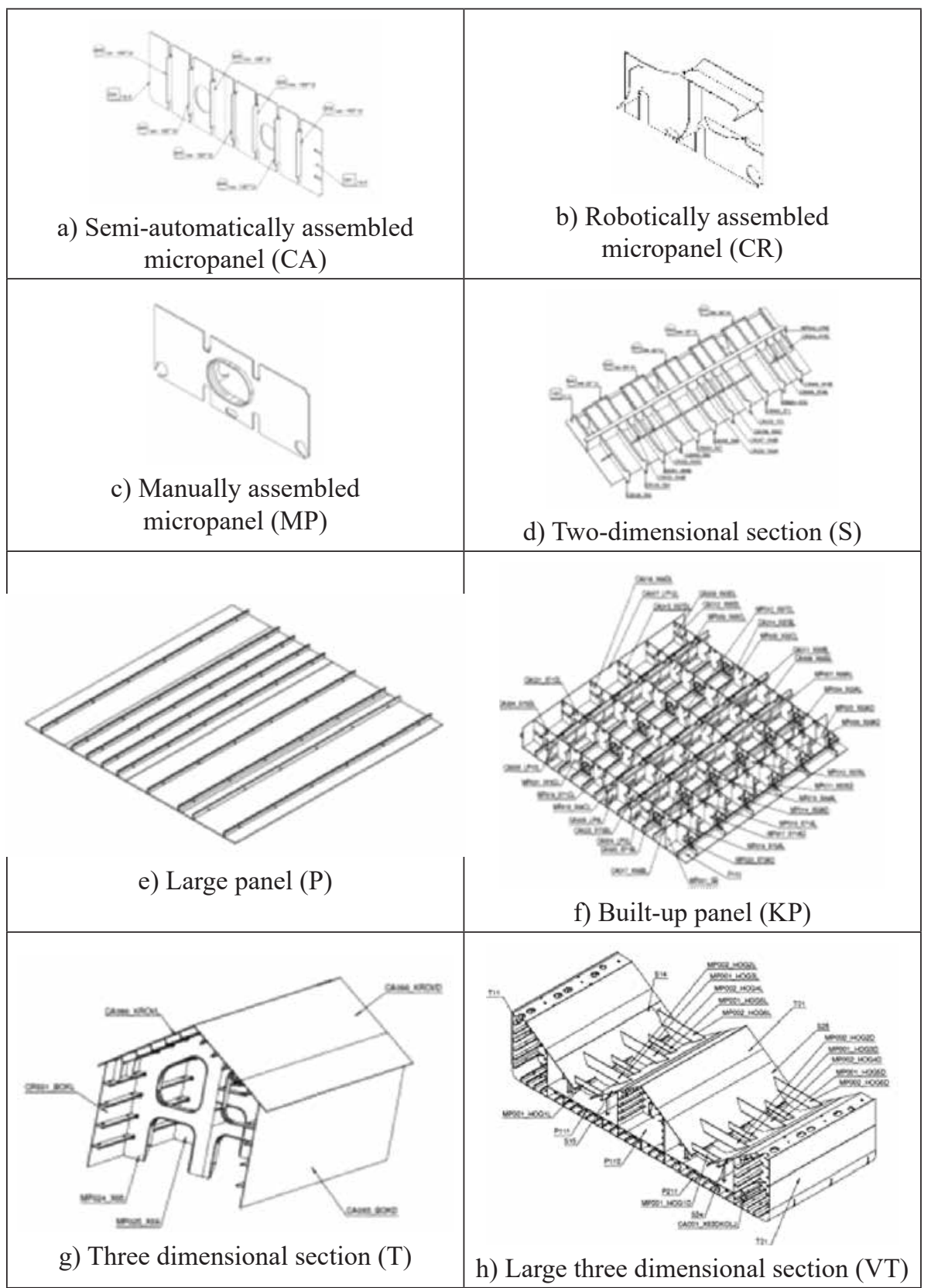

Figure 2. Illustration of interim product types 
The different interim products once assembled in their specialized production lines are then transported and assembled in the gigantic assembly hall as demonstrated in Figure 3 below.

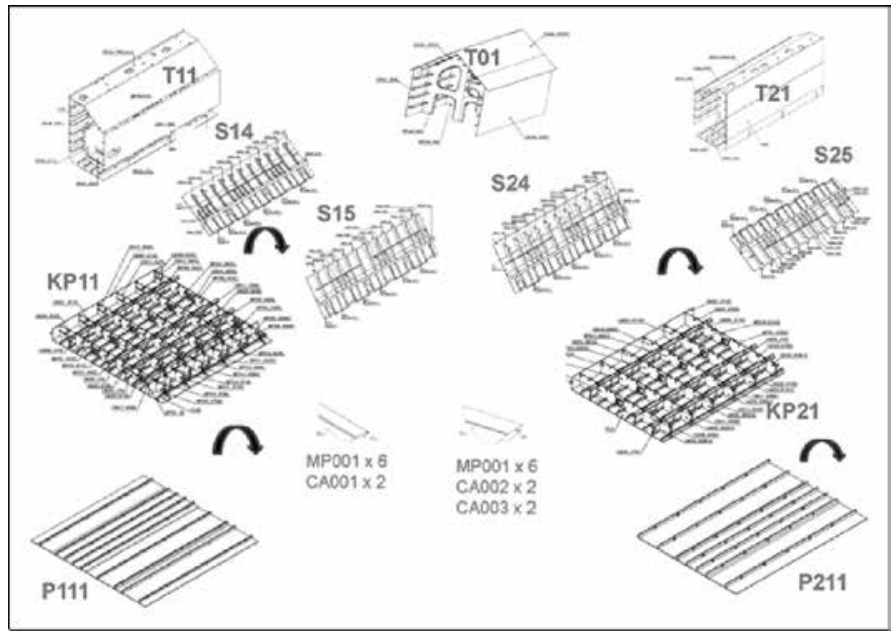

Figure 3. Interim product breakdown of a large erection block

The masses of each interim product is listed and summed up in Table 1 below, which yields a total of $148523 \mathrm{~kg}$ or 148.523 tons.

Table 1. Erection block interim product breakdown PBS

\begin{tabular}{|c|c|}
\hline Interim product & Mass (kg) \\
T01 & 17869,79 \\
T11 & 24239,85 \\
T21 & 24239,85 \\
S14 & 16559,02 \\
S15 & 4757,67 \\
S24 & 4299,07 \\
S25 & 11690,94 \\
KP11 & 19570,5 \\
KP21 & 14483,6 \\
P111 & 13817,6 \\
P211 & 10139,3 \\
Misc. elements & 2502,96 \\
Misc. micropanels & 5356 \\
& $\mathbf{1 4 8 5 2 3}$ \\
\hline
\end{tabular}




\subsection{Car carrier}

The dimensions of the car-carrier built in the Uljanik shipyard are 199,90 $\mathrm{m}$ long, $32,3 \mathrm{~m}$ wide, with a capacity of over 7000 cars. The desginations of the interim products have similarities to the interim products of 3 . Maj (See Table 2). The parallel middle body breakdown is illustrated in Figure 4.

Table 2. Interim product designations at Uljanik and 3. Maj shipyards

\begin{tabular}{|c|c|c|}
\hline $\begin{array}{c}\text { Uljanik shipyard } \\
\text { designation } \\
\text { SU }\end{array}$ & $\begin{array}{c}\text { 3 Maj shipyard } \\
\text { designation } \\
\text { VT }\end{array}$ & Description \\
\hline S (3D) & T & Three dimensional section \\
\hline S (2D) & S & Three dimensional section \\
\hline P & P & Panel \\
\hline N & KP & Built-u panel \\
\hline M & MP & Manually assembled micropanel \\
\hline R & CR & Robotically assembled micropanel \\
\hline A & CA & Semi-automatically assembled micropanel \\
\hline
\end{tabular}

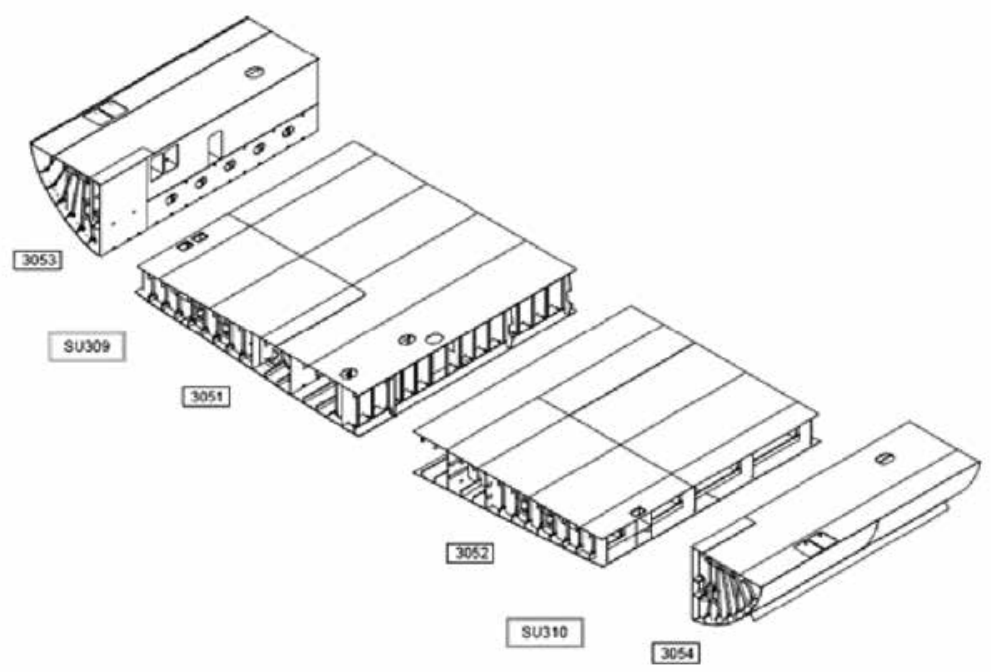

Figure 4. Interim product breakdown of a large erection block of a 7000 vehicle car carrier at shipyard $B$ 
The SU erection blocks 309 and 310 consist of four interim products labeled as sections S1 to S4. SU 309 has two sections as does SU 310. See Table 3 and Figure 5. The SU abbrevation of Uljanik shipyard is synonomous to the VT designation used by the 3. Maj shipyard.

Table 3. Erection block interim product breakdown PBS

\begin{tabular}{|c|c|c|}
\hline $\begin{array}{c}\text { SU Erection block number } \\
\text { designation }\end{array}$ & $\begin{array}{c}\text { Block } \\
\mathrm{S}\end{array}$ & Mass (tons) \\
\hline 309 & $1+3$ & 101,168 \\
\hline 310 & $2+4$ & 87,587 \\
\hline
\end{tabular}

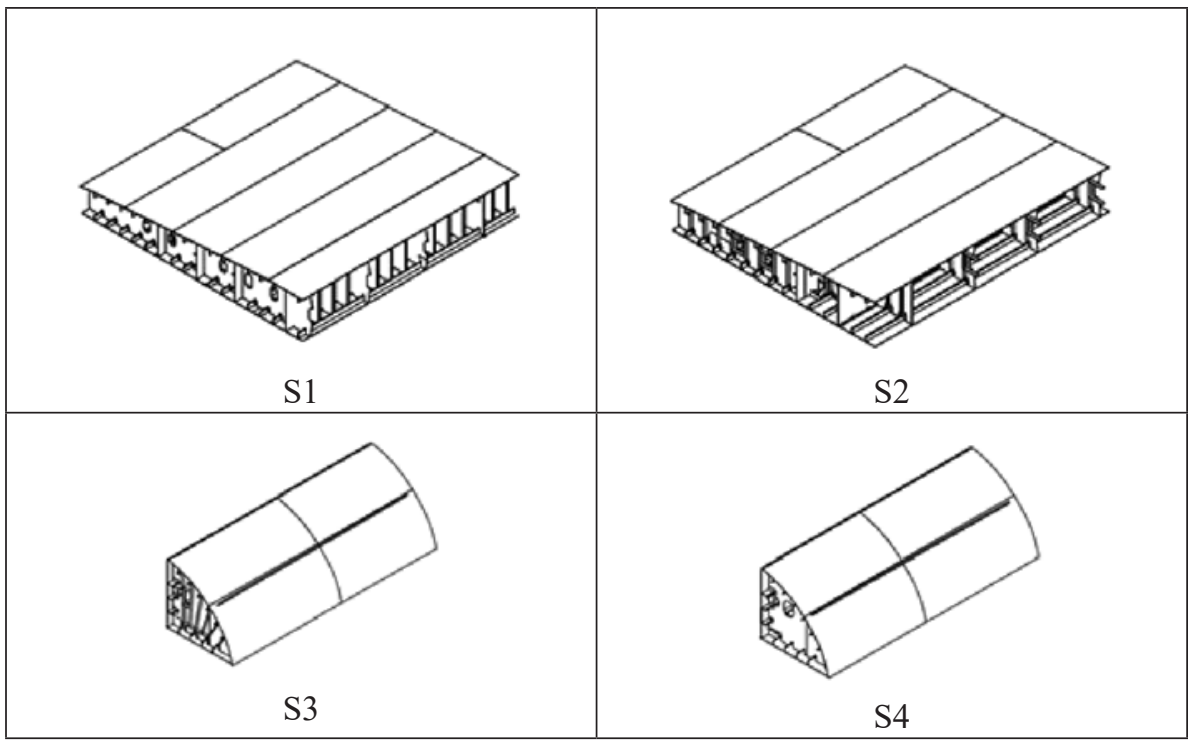

Figure 5. Close-up illustration of the interim product breakdown

The erection block 309 consists of two three-dimensional sections with a PBS shown in Table 4. Likewise, Table 5 shows the PBS of Erection block 310.

Table 4: PBS of Erection block 309

\begin{tabular}{|c|c|c|}
\hline 3D section & $\begin{array}{c}\text { Erection block } \\
\text { designation }\end{array}$ & Mass (tons) \\
\hline S1 & 309 & 70,792 \\
\hline S3 & 309 & 30,376 \\
\hline Total & & 101,168 \\
\hline
\end{tabular}


Table 5: PBS of Erection block 310

\begin{tabular}{|c|c|c|}
\hline 3D section & $\begin{array}{c}\text { Erection block } \\
\text { Designation }\end{array}$ & Mass (tons) \\
\hline S2 & 310 & 57,18 \\
\hline S4 & 310 & 30,407 \\
\hline Total & & 87,587 \\
\hline
\end{tabular}

A further breakdown of the micro-panel types are illustrated in Figure 6. In Uljanik shipyard, the micropanels labelled a and b are both done manually, whereas in 3. Maj shipyard, b would be performed by the robot, which results in less manual work, thereby yielding man-hour savings.

\begin{tabular}{|c|c|c|c|}
\hline \\
a) $834 \mathrm{M}$
\end{tabular}

Figure 6. Micropanels a,b)manually assembled $c, d$ )robotically assembled, $e, f$ ) semi-automatically assembled

Figure 7 below shows the large erection blocks at both 3. Maj shipyard and Uljanik shipyard. Uljanik shipyard has a greater breakdown due to having a smaller crane capacity, 150 tons vs 300 tons at 3. Maj shipyard. 


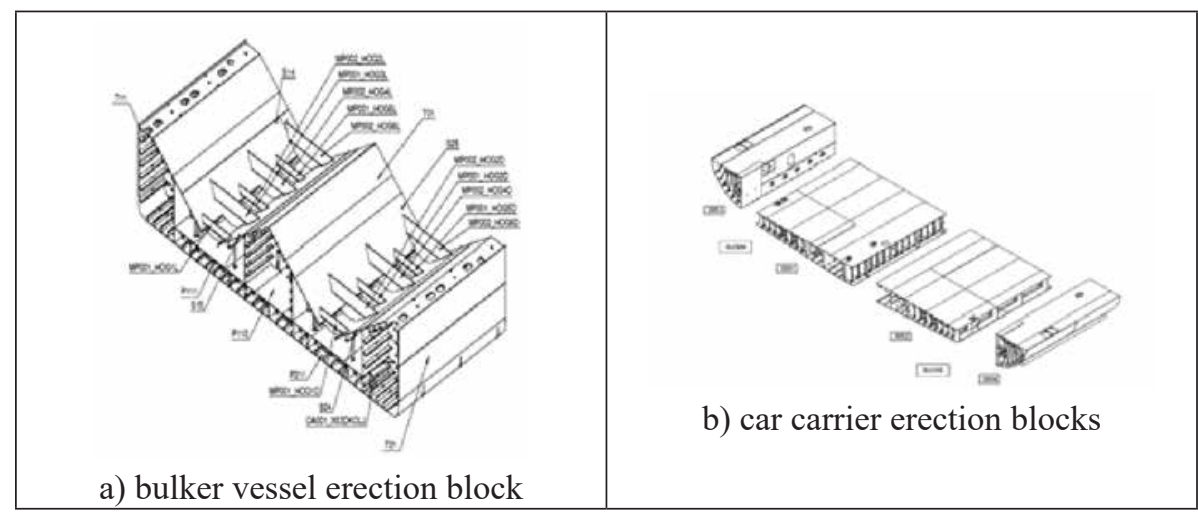

Figure 7. Double bottom erection blocks of the a)bulker vessel and b) car carrier SU309 and SU310 erection blocks

\section{Discussion}

The main difference is that even though the two large erection blocks have great mass, 148 tons for the bulker erection block and 188 tons for the car carrier, the car carrier is divided into two erection blocks SU309 which has a mass of 101 tons and SU310 with a mass of 87,6 tons. This is due to the fact that the crane capacity at shiyard $\mathrm{B}$ is smaller and therefore is not able to assemble larger erection blocks.

The designations of all of the interim products at the 3. Maj shipyard follow a clearer logic. For instance, from walking around the 3. Maj shipyard, it is very easy to differentiate which sections and elements were designed by the engineering/design office of 3. Maj shipyard from the Uljank shipyard designs. Each interim product designed by 3. Maj is readily identifiable from the labelling method. By looking at either a fabricated longitudinal stiffener or a steel plate, it is identifiable by the hierarchical structure. Each steel element tells a story about how it will evolve in the downstream production process. For instance whether it will be assembled as a micropanel or a panel. Likewise, half of all assembled panels remain as panels and the other half transform to built-up panels. Then the assembly of a panel and a built-up panel result in a very large three-dimensional section. This clear labelling and PWBS system means that less time is spent in determing where to transfer the interim products in the downstream shipbuilding processes. For instance, some micropanels are sent ot the built-up panel assembly, while others may need to be sent to the large erection hall as was the case in this paper for the bulker larger three-dimensional seciton analyzed in this paper. 


\section{Conclusions}

There are similarities and differences in the product work breakdown structures of both shipyards. The key differences are that 3 . Maj shipyard has a much more logical PWBS system which is clearer for everyone, and does not look like esoterical bar-code labelling system which Uljanik shipyard uses. When 3. Maj shipyard uses Uljanik production drawings instead of transforming them to be in full compliance with its own facilities, then the production man-hours become significantly higher. Therefore, since both 3. Maj and Uljanik shipyards are part of the same holding corporation, when it comes to PWBS, it would be proper to adopt the 3. Maj shipyard system. This would drive down the man-hours thereby yielding major savings for the entire Uljanik group.

\section{Literature}

1. Design for Production Manual. 1999 Design for Production Manual, $2^{\text {nd }}$ edition, National Shipbuilding Research Program, U.S. Department of the Navy Carderock Division, Vol. 1-3.

2. Kolić, D., Fafandjel, N., Calić, B.: 2010 Determining how to apply the design for production concept in shipyards through risk analysis, Engineering Review, Faculty of Engineering, University of Rijeka, Vol. 30, No. 1, ISSN: 1330-9587, 2010.

3. Vukman, M., Kolić, Fafandjel, N., Hadjina, M., 2016 DFP Analysis of robotically assembled interim products in shipbuilding, Pomorski zbornik, 1, 1, 111-119.

4. Kolić, Damir, Storch, R.L., Fafandjel, N. 2012a Lean manufacturing methodology for shipyards Brodogradnja 63, 1, 56-64.

5. Kolich, D. Storch, R.L., Fafandjel, N, 2012b Value stream mapping methodology for preassembly steel processes in shipbuilding, Proceedings The International Conference on Innovative Technologies, IN-TECH, September 26-28, Rijeka, Croatia.

6. Kolich, D., Yao, Y.L., Fafandjel, N. and Hadjina, M. 2014 Value Stream Mapping Micropanel Assembly with Clustering to Improve Flow in a Shipyard Proceedings The International Conference on Innovative Technologies, ISBN: 978-953-6326-884, p.85-88, IN-TECH, September 10-12, Leiria, Portugal, 85-88.

7. Kolich, D., Yao, Y.L., Neuberg, R., Storch, R.L. and Fafandjel, N. 2015b Data mining to predict laser hybrid laser arc welding improvements in ship interim product assembly, Proceedings, The International Conference of Computer Applications in Shipbuilding, Royal Institute of Naval Architects, September 29 - October 2, Bremen, 137-168.

8. Kolich, D., Storch, R.L., Fafandjel, N. 2015a Optimizing shipyard interim product assembly using a value stream mapping methodology, Proceedings, World Maritime Technology Conference Papers Society of Naval Architects and Marine Engineers, November 3-7, Rhode Island, 1-10.

9. Kolich,D., Storch, R.L., Fafandjel, N. 2017a Lean methodology to transform shipbuilding panel assembly, Journal of Ship Production and Design, 33, 1, 1-10.

10. Kolich,D., Storch, R.L., Fafandjel, N. 2016 Lean transformation of built-up panel assembly in shipbuilding using a value stream mapping methodology, Proceedings, SNAME Maritime Conference Papers Society of Naval Architects and Marine Engineers, November 1-5, Bellevue, Washington, 1-10.

11. Kolich,D., Storch, R.L., Fafandjel, N. 2017b Lean built-up panel assembly in a newbuilding shipyard, Journal of Ship Production and Design, 0, 0, 1-9.

12. Kolich, D., Sladic, S., Storch, R.L. 2017c Lean IHOP Transformation of Shipyard Erection Block Construction, Proceedings, SNAME Maritime Convention, October 23-28, Houston. 
Vanda Brandić, Damir Kolić

\section{PWBS analiza najbolje prakse dvaju brodogradilišta}

\section{Sažetak}

Detaljna tehnološka raščlana međuproizvoda (PWBS) jednog brodogradilišta definira podjelu prouzvoda i podjelu rada. Brodogradilišta koja imaju dobro definiranu detaljnu tehnološku raščlanu međuproizvoda učinkovito smanjuju broj radnih sati koristeći blokovsku metodu gradnje trupa (HBCM). U ovome su radu analizirani tipični blokovi dvodna broda za prijevoz automobila i broda za prijevoz rasutog tereta s automatiziranim istovarom projektiranih u različitim brodogradilištima. Budući da svako brodogradilište koristi različitu raščlanu međuproizvoda (PBS), tabličnom usporedbom će se prikazati koja je raščlana bolja.

Zaključak je da različita brodogradilišta pod istom upravom trebaju objektivno primjenjivati metode najbolje prakse koje prepoznaju i, ono što je najbolje u jednom brodogradilištu, primjenjivati u drugome i obrnuto. To će povećati razinu konkurentnosti oba brodogradilišta.

Ključne riječi: Detaljna tehnološka raščlana međuproizvoda - PWBS; brodogradnja; blokovska metoda gradnje trupa - HBCM 
